\title{
32. PRELIMINARY ASSESSMENT OF CYCLIC VARIATIONS IN FORAMINIFERS, BARITE, AND CADMIUM/CALCIUM RATIOS IN EARLY PLEISTOCENE SEDIMENTS FROM HOLE 709C (EQUATORIAL INDIAN OCEAN) ${ }^{1}$
}

\author{
Julian E. Andrews, ${ }^{2}$ Brian M. Funnell, ${ }^{2}$ Timothy D. Jickells, ${ }^{2}$ Nicholas J. Shackleton, ${ }^{3}$ Jane E. Swallow, ${ }^{3}$ \\ Ann C. Williams, ${ }^{2}$ and Kathryn A. Young ${ }^{2}$
}

\begin{abstract}
During three to four $\delta^{18} \mathrm{O}$ cycles (determined on Globigerinoides ruber), more positive $\delta^{18} \mathrm{O}(=$ higher global ice volume) values correlated with higher Globorotalia menardii percentages, total numbers of benthic foraminifers, number of benthic foraminifer species, and the percent of total foraminifers composed of benthic foraminifers. During the same intervals, barite and insoluble residues also generally recorded higher values; however, there was no clear evidence of systematic variation in cadmium/calcium ratios (in benthic foraminifers). Maximum percentages of Globigerinoides sacculifer and Globigerinoides ruber correlate with more negative $\delta^{18} \mathrm{O}(=$ lower global ice volume) values, although they sometimes appear to lead the $\delta^{18} \mathrm{O}$ changes by $<\simeq 4,000 \mathrm{yr}$.

The increase in percentage of the tropical "divergence" planktonic foraminifer species G. menardii and the reduction of the "nondivergence" tropical species G. ruber and G. sacculifer at times of inferred ice growth is attributed to periodic intensification of divergence associated with the Equatorial Counter Current. Barite and insoluble residue sedimentation at the site also generally show a relative increase at those times.
\end{abstract}

\section{INTRODUCTION}

Early Pleistocene carbonate oozes from the equatorial Indian Ocean (Ocean Drilling Program [ODP] Hole 709C, $03^{\circ} 54.9^{\prime} \mathrm{S}, 60^{\circ} 33.1^{\prime} \mathrm{E}, 3038-\mathrm{m}$ water depth) exhibit cyclic variations in the $\delta^{18} \mathrm{O}$ signal, anticipated (cf. Shackleton et al., 1988) to be on an approximately 41,000-yr (Milankovitch obliquity) frequency (Fig. 1). The purpose of this investigation was to examine the relationship between this cyclicity and variations in selected micropalaeontologic and geochemic parameters relating to surface- and bottom-water conditions at the site during part of the early Pleistocene.

Assuming an approximate overall sedimentation rate of 10.74 $\mathrm{m} / \mathrm{m}$.y., obtained by interpolation between the Olduvai Event and the Brunhes/Matuyama boundary in Hole 709A (see Schneider and Kent, this volume), the interval studied (13.35-15.30 mbsf) corresponds to $\simeq 181.6 \mathrm{k} . \mathrm{y}$. of sediment accumulation, and our sample interval of $5 \mathrm{~cm}$ (Table 1) corresponds to a period of $=4.7 \mathrm{k}$.y. Extrapolation of the same sedimentation rate to the whole of the Pleistocene section at Hole 709C suggests that the $\delta^{18} \mathrm{O}$ cycles we are considering fall close to stage 50 (1.371 Ma) of the early Pleistocene time-scale (Ruddiman et al., 1989), but precise identification of these stages awaits further refinement of the $\delta^{18} \mathrm{O}$ data set (Shackleton, this volume).

We examined five sets of variables for this study:

1. Planktonic foraminifers (Figs. 2A-2C). In particular, we counted percentages of the species Globigerinoides sacculifer, Globigerinoides ruber, and Globorotalia menardii. G. sacculifer and $G$. ruber are shallow-dwelling tropical species that are most abundant in the warm-water, tropical assemblages of the modern Indian Ocean (Bé and Hutson, 1977; Wright and Thunell,

\footnotetext{
${ }^{1}$ Duncan, R. A., Backman, J., Peterson, L. C., et al., 1990. Proc. ODP, Sci. Results, 115: College Station, TX (Ocean Drilling Program).

2 School of Environmental Sciences, University of East Anglia, Norwich, NR4 7TJ, United Kingdom.

3 The Godwin Laboratory, Free School Lane, Cambridge, CB2 3RS, United Kingdom.
}

1988). G. menardii is also a tropical species, but it is most abundant, as in the Atlantic Ocean (McIntyre et al., 1989), in the "divergence" assemblages at the margins of the Equatorial Counter Current (ECC) of the present-day Indian Ocean.

2. Benthic foraminifers (Figs. 3A-3C). We record the percentage of benthic foraminifers (of total foraminifers), the number of specimens (per $5 \mathrm{ml}$ of sediment), and the number of species (per $5 \mathrm{ml}$ of sediment). These parameters may reflect either relative dissolution of benthic vs. planktonic foraminifers or availability of food (productivity) at the seafloor. Considering the depth of Site $709(3038 \mathrm{~m})$, we think that the variability is more likely to result from relative production than relative dissolution differences in benthic vs. planktonic foraminifers.

3. Cadmium/calcium $(\mathrm{Cd} / \mathrm{Ca})$ ratios in benthic foraminifers (Fig. 4A). Where sufficient specimens were available, we determined this ratio as a proxy for $\mathrm{PO}_{4}$ concentrations in the bottom waters (cf. Boyle, 1988). Numbers of benthic foraminifers were, however, sometimes deficient, particularly in the low $\delta^{18} \mathrm{O}$ samples.

4. Barite in the sediment fine $(<150-\mu \mathrm{m})$ size fraction (Fig. 4B). Percentage of barite was measured in the expectation that it would provide an index of surface-water productivity. Church (1979) has found that micro- $(2-4 \mu \mathrm{m})$ barite accumulates in bottom sediments beneath the equatorial high productivity zones of the Pacific, Atlantic, and Indian oceans. Barite has also been found in the water column in the same situations (Dehairs et al., 1980; Bishop, 1988). Away from continental margins and midocean-ridge sites (where weathering and hydrothermal barite may occur), it is generally agreed that deep-sea microbarite is biogenic and produced either in the protoplasm of protozoans and algae (Schmitz, 1987), from heterotrophic organisms below the euphotic zone (Dehairs et al., 1987), or from precipitation of barite in sedimenting fecal pellets (Dehairs et al., 1980; Bishop, 1988). Although accumulation of such barite in sediments is affected by both water column dissolution (Dehairs et al., 1980) and early diagenetic remobilization, its presence in present-day sediments is clearly correlated with surface-water productivity.

5. Acid insoluble residues (IR) of the fine $(<150-\mu \mathrm{m})$ size fraction (Fig. 4C). Assuming uniform supply rates of detrital material, we measured \% IR as a possible indicator of fluctua- 


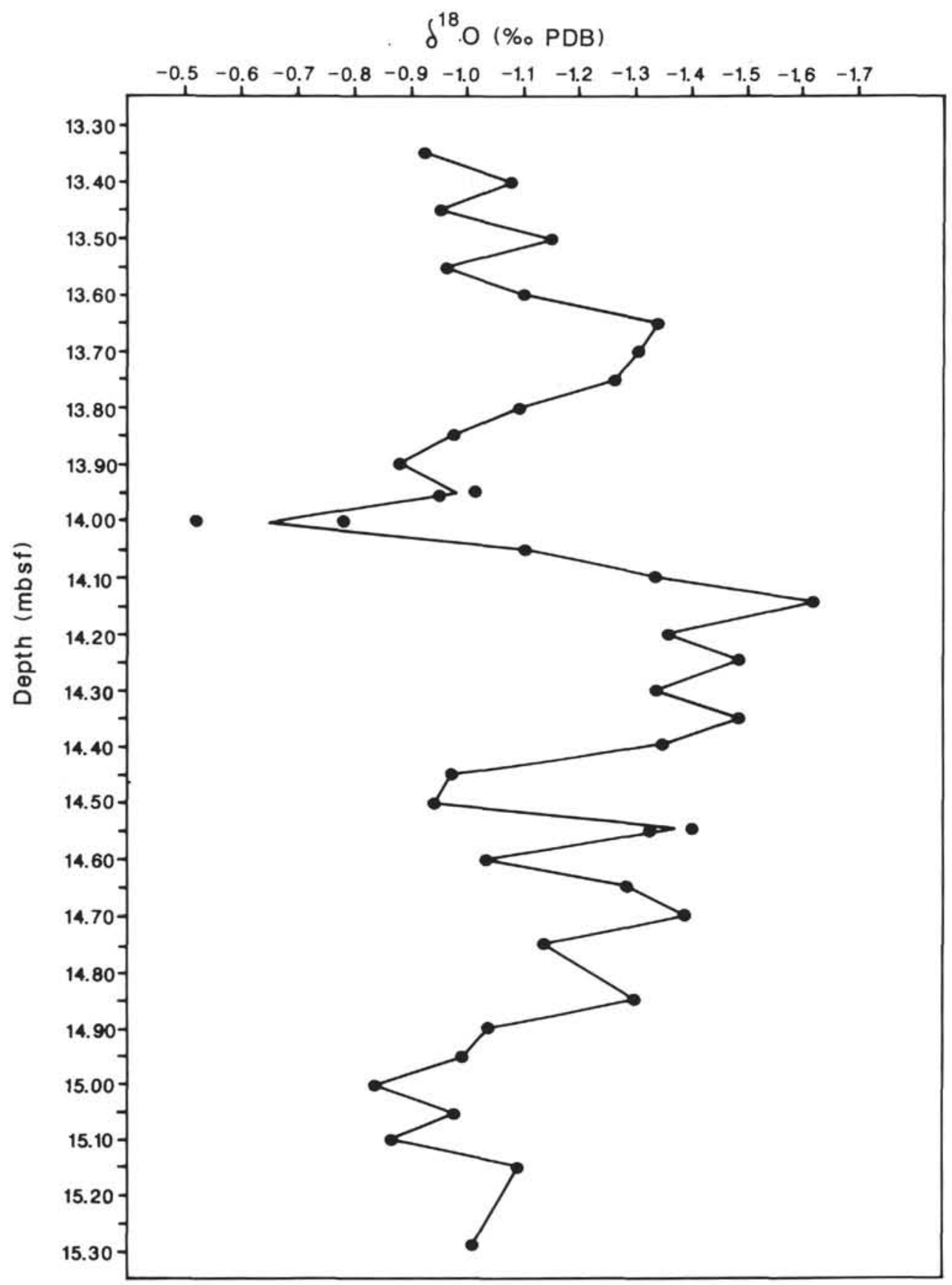

Figure $1 . \delta^{18} \mathrm{O}\left(\mathrm{N}^{\circ}\right.$ vs. PDB) determined on Globigerinoides ruber.

tions in the rate of supply of calcium carbonate to the seafloor. However, we also recognize $\%$ IR as a potential index of paleowind strength as stronger winds transport more aeolian dust (e.g., Boyle, 1983). The geochemistry of the noncarbonate fraction was also analyzed in an attempt to monitor changes in the composition of the IR, which might reflect changes in the source region or wind strength (Boyle, 1983).

\section{METHODS}

The samples listed in Table 1 combine the ones obtained for this project with those for stable isotope analyses (Shackleton, this volume). They were washed and separated into $>150-$ and $<150-\mu \mathrm{m}$ size fractions at the Godwin Laboratory, Cambridge, using that laboratory's standard methods.

\section{Foraminifers}

In addition to the foraminifers picked for stable isotope analysis at Cambridge, an aliquot of each sample was picked for approximately 300 planktonic foraminifers, and the benthic/ planktonic foraminifer ratio was determined at the same time. One half of each $(10-\mathrm{ml})$ sample was subject to total extraction of the benthic foraminifers, which were analyzed to determine their $\mathrm{Cd} / \mathrm{Ca}$ ratios whenever they were sufficiently numerous.

\section{Cadmium/Calcium Ratios in the Benthic Foraminifers}

The benthic foraminifers were cleaned and analyzed with methods developed by Boyle (1988) and previously used by us on samples from Leg 112 (Jickells et al., in press). The high di- 


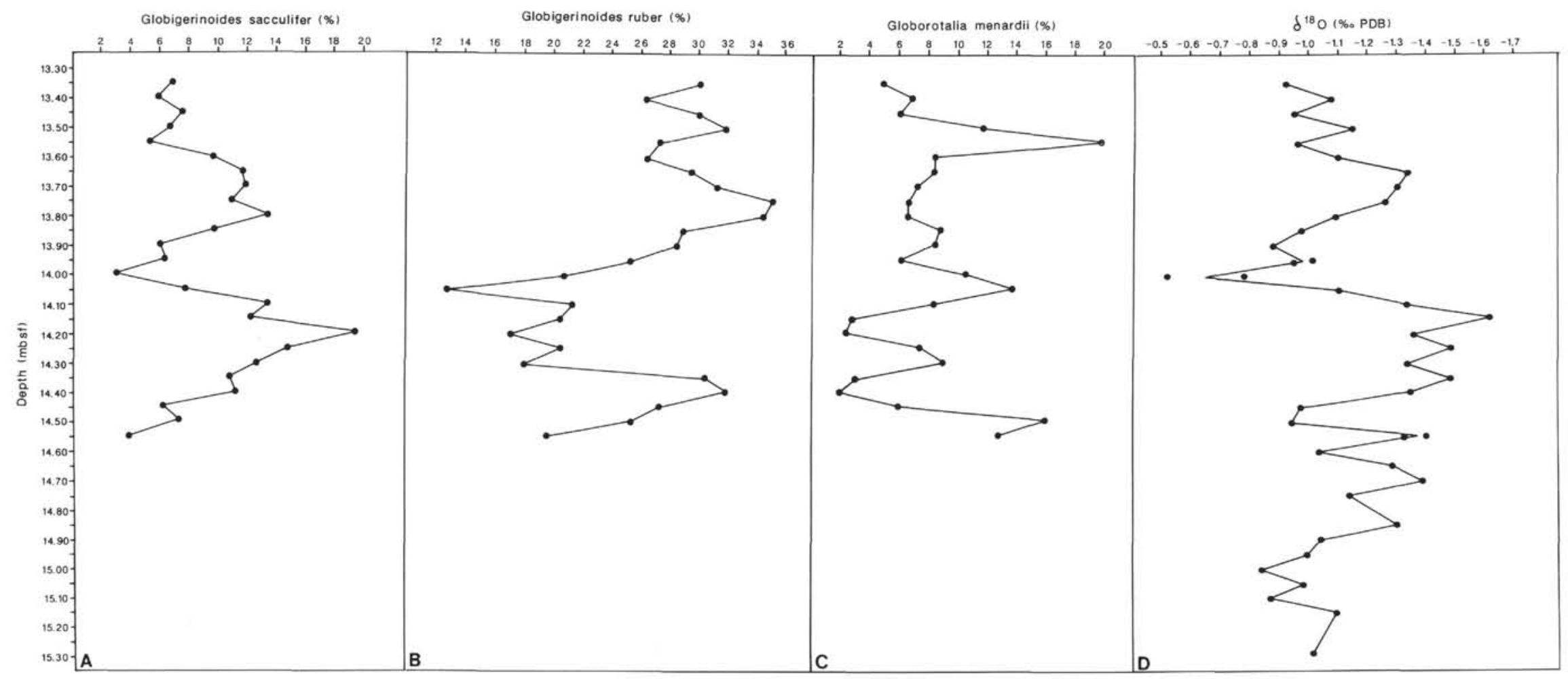

Figure 2. Percentage of planktonic foraminifers in the $>150-\mu \mathrm{m}$ size fraction on the basis of an $\simeq 300$-sample count. A. Globigerinoides sacculifer. B. Globigerinoides ruber. C. Globorotalia menardii $\mathbf{D} . \delta^{18} \mathrm{O}$. 


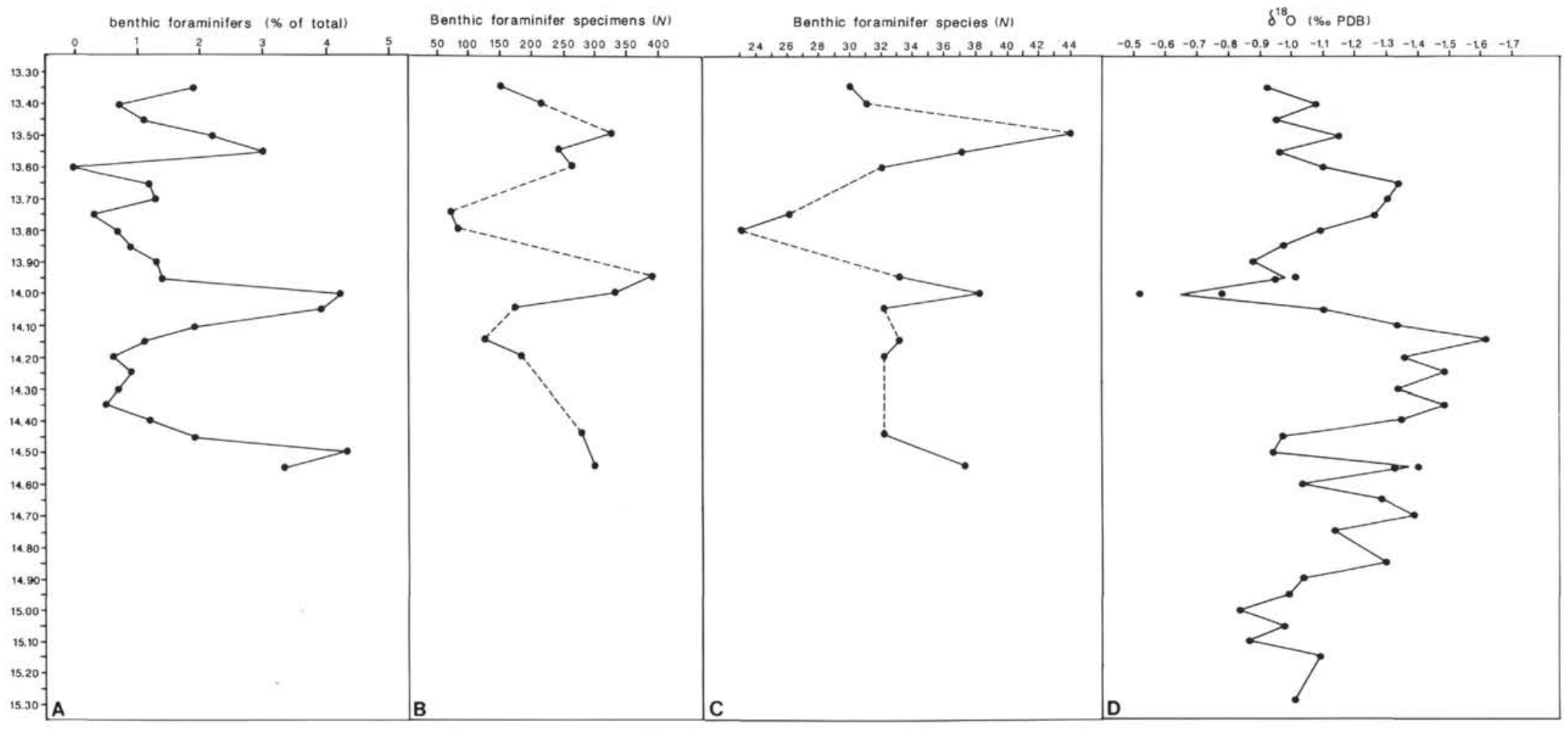

Figure 3. A. Benthic foraminifer abundance as a percentage of total foraminifers. B. Number of specimens of benthic foraminifers in $5 \mathrm{ml}$ of sediment. C. Number of species of benthic foraminifers in $5 \mathrm{ml}$ of sediment. D. $\delta^{18} \mathrm{O}$. 


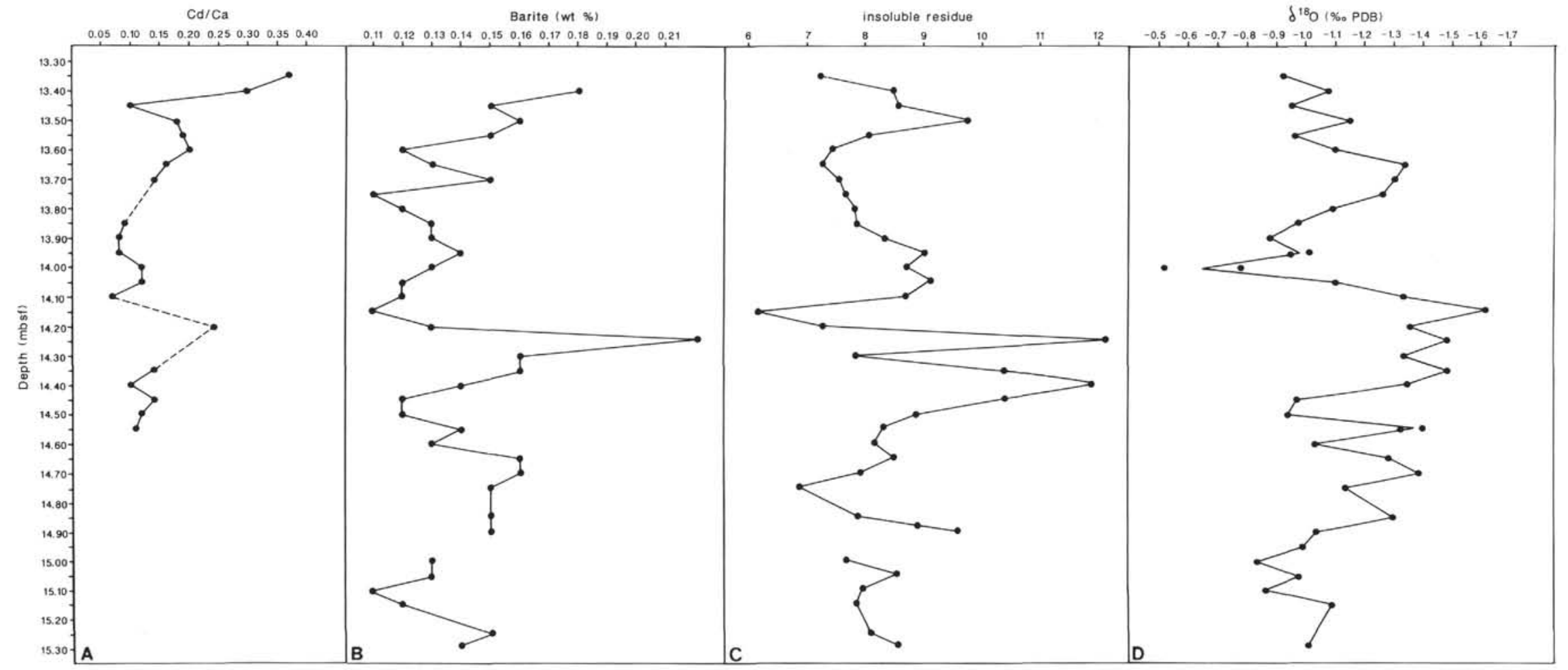

Figure 4. A. Cadmium/Calcium (Cd/Ca) ratios in the benthic foraminifer Uvigerina hispidocostata vs. depth. B. Barite (wt\%) in the $<150-\mu \mathrm{m}$ size fraction. C. Percentage of insoluble residue (IR) by weight in the $<150-\mu \mathrm{m}$ size fraction. D. $\delta^{18} \mathrm{O}$. 
Table 1. Samples investigated in this study.

\begin{tabular}{ll}
\hline $\begin{array}{l}\text { Core, section, } \\
\text { interval (cm) }\end{array}$ & $\begin{array}{c}\text { Depth } \\
\text { (mbsf) }\end{array}$ \\
\hline $115-709$ C. & \\
2H-6, 5-7 & 13.35 \\
2H-6, 10-12 & 13.40 \\
$2 \mathrm{H}-6,15-17$ & 13.45 \\
$2 \mathrm{H}-6,20-22$ & 13.50 \\
$2 \mathrm{H}-6,25-27$ & 13.55 \\
$2 \mathrm{H}-6,30-32$ & 13.60 \\
$2 \mathrm{H}-6,35-37$ & 13.65 \\
$2 \mathrm{H}-6,40-42$ & 13.70 \\
$2 \mathrm{H}-6,45-47$ & 13.75 \\
$2 \mathrm{H}-6,50-52$ & 13.80 \\
$2 \mathrm{H}-6,55-57$ & 13.85 \\
$2 \mathrm{H}-6,60-62$ & 13.90 \\
$2 \mathrm{H}-6,65-67$ & 13.95 \\
$2 \mathrm{H}-6,70-72$ & 14.00 \\
$2 \mathrm{H}-6,75-77$ & 14.05 \\
$2 \mathrm{H}-6,80-82$ & 14.10 \\
$2 \mathrm{H}-6,85-87$ & 14.15 \\
$2 \mathrm{H}-6,90-92$ & 14.20 \\
$2 \mathrm{H}-6,95-97$ & 14.25 \\
$2 \mathrm{H}-6,100-102$ & 14.30 \\
$2 \mathrm{H}-6,105-107$ & 14.35 \\
$2 \mathrm{H}-6,110-112$ & 14.40 \\
$2 \mathrm{H}-6,115-117$ & 14.45 \\
$2 \mathrm{H}-6,120-122$ & 14.50 \\
$2 \mathrm{H}-6,125-127$ & 14.55 \\
$2 \mathrm{H}-6,130-132$ & 14.60 \\
$2 \mathrm{H}-6,135-137$ & 14.65 \\
$2 \mathrm{H}-6,140-142$ & 14.70 \\
$2 \mathrm{H}-6,145-147$ & 14.75 \\
$2 \mathrm{H}-7,5-7$ & 14.85 \\
$2 \mathrm{H}-7,10-12$ & 14.90 \\
$2 \mathrm{H}-7,15$ & 14.95 \\
$2 \mathrm{H}-7,20$ & 15.00 \\
$2 \mathrm{H}-7,25$ & 15.05 \\
$2 \mathrm{H}-7,20$ & 15.10 \\
$2 \mathrm{H}-7,35$ & 15.15 \\
$2 \mathrm{H}-\mathrm{CC}, 5-7$ & 15.25 \\
$2 \mathrm{H}-\mathrm{CC}, 10-12$ & 15.30 \\
& \\
&
\end{tabular}

versity, but in many samples low total abundances, of benthic foraminifers in these highly calcareous, planktonic-foraminiferdominated sediments made it difficult to obtain consistent yields of suitable species for $\mathrm{Cd}$ analysis from successive samples. Therefore, the continuity of our determinations for $\mathrm{Cd}$ is much less satisfactory than for the other parameters measured on these samples. The most suitable species that occurred in sufficient numbers for adequate analyses to be made was Uvigerina hispidocostata.

\section{Elemental Analysis of $<\mathbf{1 5 0}-\mu \mathrm{m}$ Size Fraction}

Approximately $5 \mathrm{~g}$ of each sample were leached in 11 of 0.3 mol acetic acid for $2 \mathrm{hr}$ to remove calcium carbonate $\left(\mathrm{CaCO}_{3}\right)$ with minimal leaching of the insoluble residue. The insoluble residues were collected by filtration, dried on preweighed filter paper, and then reweighed. Part of the residue was mineralogically analyzed by X-ray diffraction (XRD), and another was prepared for elemental analysis. We weighed $0.1 \mathrm{~g}$ into a clean PTFE beaker and added $3 \mathrm{ml}$ of concentrated hydrofluoric/perchloric $\left(\mathrm{HF} / \mathrm{HClO}_{4}\right)$ acid in a 2:1 ratio. The beaker was then heated to $250^{\circ} \mathrm{C}$ and evaporated to dryness. After cooling, the residual salts were dissolved in $1 \mathrm{ml}$ of concentrated hydrochloric acid $(\mathrm{Hcl})$ and a few drops of milli-Q water and were made up to $10 \mathrm{ml}$ by weight.

At this stage, barite (confirmed by XRD), formed as a white precipitate that was then separated from the solution by centrifuging. The barite precipitate was dissolved in $2 \mathrm{ml}$ of $1 \%$
$\mathrm{KOH} / \mathrm{EDTA}$ at $90^{\circ} \mathrm{C}$ for $2 \mathrm{hr}$ and was then made up to $10 \mathrm{ml}$ by weight when cool. The solutions were analyzed for aluminum, magnesium, potassium, manganese, strontium, barium, iron, zinc, and titanium with a Phillips inductively coupled plasma source atomic emission spectrometer (ICP) (see Walsh and Howie, 1986), except for the dissolved barite precipitate in which $\mathrm{Ba}$ was determined by flame atomic absorption spectrophotometer (AAS). Precision was better than $1 \%$ for all elements. Insignificant amounts of all the analyzed elements were found in the acetic acid leach, confirming the selectivity of this technique for leaching $\mathrm{CaCO}_{3}$. Significant amounts of $\mathrm{Ba}$ were found in the $\mathrm{HF} / \mathrm{HClO}_{4}$ digest as well as in the $\mathrm{KOH} /$ EDTA digest.

Total $\mathrm{Ba}$ values $\left(\mathrm{HF} / \mathrm{HClO}_{4}+\mathrm{KOH} / \mathrm{EDTA}\right.$ digests) were converted to wt $\%$ barite by correcting for average crustal barium (Turekian and Wedepohl, 1961), which accounts for barium contributions from clay minerals. Barium in the carbonate fraction was insignificant. The following conversion was applied:

$$
\left(\frac{\mathrm{Ba}}{\mathrm{Al}}\right)_{\text {crust }} \times \mathrm{Al}_{\text {sample }}=\mathrm{Ba}_{\text {crust }},
$$

where $\mathrm{Ba}_{\text {barite }}=\mathrm{Ba}_{\text {sample }}-\mathrm{Ba}_{\text {crust }}$. We then recast $\mathrm{Ba}_{\text {barite }}$ in ppm as $w \mathrm{t} \%$ barite.

\section{RESULTS}

\section{Planktonic Foraminifers}

Percentage abundances of three species were determined. Plots for Globigerinoides sacculifer (Fig. 2A) closely mimic the $\delta^{18} \mathrm{O}$ curve, whereas those for Globigerinoides ruber (Fig. 2B) follow the $\delta^{18} \mathrm{O}$ curve less closely. Globorotalia menardii (Fig. 2C) shows an inverse relationship to the two Globigerinoides species.

\section{Benthic Foraminifers}

The percentage of benthic foraminifers out of the total foraminifers (Fig. 3A) varies cyclically, as does the number of specimens and the number of species (Figs. 3B-3C) obtained from half of the $>150-\mu \mathrm{m}$ size fraction of a standard $10-\mathrm{ml}$ sediment sample. The percentage, number of specimens, and number of species are highest during periods of high $\delta^{18} \mathrm{O}$.

\section{Cd/Ca Ratios in Benthic Foraminifers}

The results of our determinations are listed in Table 2 and shown in Figure 4.

\section{Elemental Geochemistry of Noncarbonate Fraction}

All of the elements analyzed (Table 3 ) correlate positively (Table 4) with increasing percentages of acid insoluble residues (significant at the 0.01 confidence level), although the relationship is weakest for strontium and barium. Percentages of IR vary from $6 \%$ to $12 \%$, and XRD analysis confirms that the IR is composed of clay minerals, quartz, and barite. Aluminum and potassium contents are positively correlated with magnesium, manganese, titanium, and zinc, indicating that these elements are mainly incorporated in the clay minerals, with increasing concentrations as the (mainly clay) \%IR increases.

Strong positive correlations between $\mathrm{Ti}$ and $\% \mathrm{IR}$ and also with iron, suggest that some $\mathrm{Ti}$ phases are present (i.e., anatase and rutile), which usually contain trace amounts of Fe (Deer et al., 1966). $\mathrm{Ba}$ and $\mathrm{Sr}$ do not correlate with the other elements, but they do covary. This indicates that $\mathrm{Ba}$ is not associated with clay minerals but is concentrated in barite (see below). The relationship with $\mathrm{Sr}$ indicates some isomorphous substitution of $\mathrm{Sr}$ for $\mathrm{Ba}$ in the barite, which is well documented (e.g., Church, 1979). 
Table 2. Cd/Ca ratios for benthic foraminifers in Hole 709C.

\begin{tabular}{ll}
\hline $\begin{array}{c}\text { Sample } \\
\text { depth } \\
\text { (mbsf) }\end{array}$ & $\begin{array}{c}\text { Average } \\
\text { Cd/Ca atomic } \\
\text { ratio } \times 10^{-6}\end{array}$ \\
\hline 13.35 & $0.37(?)$ \\
13.40 & $0.30(?)$ \\
13.45 & $0.10 \pm 0.04$ \\
13.50 & 0.18 \\
13.55 & 0.19 \\
13.60 & 0.20 \\
13.65 & 0.16 \\
13.70 & 0.14 \\
13.85 & 0.09 \\
13.90 & 0.08 \\
13.95 & $0.8 \pm 0.03$ \\
14.00 & $0.12 \pm 0.03$ \\
14.05 & 0.12 \\
14.10 & 0.07 \\
14.20 & 0.24 \\
14.35 & 0.14 \\
14.40 & 0.10 \\
14.45 & $0.14 \pm 0.08$ \\
14.50 & 0.12 \\
14.55 & $0.11 \pm 0.03$ \\
\hline & \\
\hline
\end{tabular}

Note: Uncertainties listed represent $1 \mathrm{SD}$ about the mean where three or more separate determinations were made. All determinations were made on Uvigerina hispidocostata. $(?)=$ possible unreliable analy-

ses.

Downcore profiles for most elements show significant perturbation at about 14.20 to 14.30 mbsf. Aluminum content generally decreases downcore (significant at the 0.1 confidence level), which might best be explained by a decrease in aluminous clay (i.e., kaolinite). Similar, but less well-marked, decreases in $\mathrm{Mg}$ and $\mathrm{K}$ are better explained by a decrease in the amount of mixedlayer, illite-smectite clay; however, XRD analyses do not show significant variation in the relative percentages of smectite, mixed-layer illite-smectite, illite, and kaolinite downcore.

\section{Variation in wt $\%$ Barite}

Barite contents generally vary from 0.11 to $0.16 \mathrm{wt} \%$ (with two maxima of 0.18 and $0.21 \mathrm{wt} \%$ ). In general, therefore, the data would be consistent with low-productivity sedimentation (i.e., < 0.2 wt \%; Schmitz, 1987). However, Schmitz notes that dissolution of barite probably occurs in deep-water sites, so the values here are probably a minimum estimate of barite sedimentation.

\section{DISCUSSION}

The $\delta^{18} \mathrm{O}$ curve (Fig. 1) for the interval we investigated was produced from analyses of the planktonic foraminifer $G$. ruber. The $\delta^{18} \mathrm{O}$ values are expected to reflect variations in global ice volume, combined with an additional effect from fluctuations in surface-water temperatures at the site. Three, perhaps four, $\delta^{18} \mathrm{O}$ maxima occur (higher ice volume/colder) at $13.35,14.00$, 14.50 , and $15.00 \mathrm{mbsf}$; and three, possibly four, $\delta^{18} \mathrm{O}$ minima occur (lower ice volume/warmer) at 13.65, 14.15, 14.55, and 15.15 mbsf. At the approximate sedimentation rate of $10.74 \mathrm{~m} /$ m.y. assumed above, the average separation of the peaks is approximately $49.0 \mathrm{k} . \mathrm{y}$, equivalent to ten samples. We think it
Table 3. Wt $\%$ insoluble residue ( $\%$ IR), and elemental analyses (in ppm).

\begin{tabular}{|c|c|c|c|c|c|c|c|c|c|c|}
\hline \multirow{2}{*}{$\begin{array}{l}\text { Depth } \\
\text { (mbsf) }\end{array}$} & \multirow{2}{*}{$\begin{array}{c}\text { Wt } \\
\% \text { IR }\end{array}$} & \multicolumn{9}{|c|}{$\begin{array}{l}\text { Major elements } \\
\text { (ppm) }\end{array}$} \\
\hline & & Al & $\mathrm{Fe}$ & $\mathrm{Mg}$ & $\mathrm{K}$ & $\mathrm{Ti}$ & Mn & $\mathrm{Ba}$ & $\mathrm{Sr}$ & $\overline{\mathrm{Zn}}$ \\
\hline 13.35 & 7.22 & 5164 & 3816 & 1265 & 1090 & 216 & 33 & - & 26 & 15 \\
\hline 13.40 & 8.49 & 5934 & 4296 & 1615 & 1275 & 329 & 33 & 1088 & 46 & 14 \\
\hline 13.45 & 8.53 & 6259 & 4724 & 1664 & 1381 & 352 & 40 & 921 & 39 & 13 \\
\hline 13.50 & 9.75 & 6700 & 5042 & 1766 & 1505 & 374 & 38 & 973 & 46 & 16 \\
\hline 13.55 & 8.04 & 4373 & 4349 & 1502 & 1200 & 251 & 31 & 886 & 43 & 15 \\
\hline 13.60 & 7.42 & 4828 & 3755 & 1362 & 1121 & 209 & 23 & 738 & 46 & 12 \\
\hline 13.65 & 7.28 & 4656 & 3571 & 1280 & 1039 & 227 & 28 & 812 & 41 & 11 \\
\hline 13.70 & 7.56 & 4996 & 3730 & 1342 & 1085 & 282 & 23 & 920 & 45 & 12 \\
\hline 13.75 & 7.66 & 5138 & 4057 & 1424 & 1125 & 251 & 24 & 653 & 39 & 9 \\
\hline 13.80 & 7.81 & 5453 & 4397 & 1528 & 1206 & 250 & 30 & 712 & 38 & 13 \\
\hline 13.85 & 7.84 & 5470 & 4416 & 1608 & 1242 & 282 & 30 & 814 & 41 & 13 \\
\hline 13.90 & 8.33 & 5600 & 5088 & 1893 & 1438 & 285 & 32 & 817 & 40 & 15 \\
\hline 13.95 & 9.01 & 6327 & 4950 & 1924 & 1481 & 271 & 35 & 874 & 46 & 15 \\
\hline 14.00 & 8.69 & 5954 & 5036 & 1918 & 1478 & 297 & 34 & 780 & 43 & 15 \\
\hline 14.05 & 9.12 & 6489 & 5207 & 1909 & 1483 & 278 & 35 & 761 & 44 & 16 \\
\hline 14.10 & 8.69 & 5618 & 4470 & 1590 & 1276 & 266 & 34 & 742 & 45 & 14 \\
\hline 14.15 & 6.17 & 3011 & 2164 & 874 & 645 & 136 & 14 & 648 & 36 & 8 \\
\hline 14.20 & 7.27 & 4780 & 3744 & 1317 & 1068 & 244 & 23 & 767 & 44 & 12 \\
\hline 14.25 & 2.10 & 7424 & 5763 & 2128 & 1668 & 371 & 38 & 1296 & 73 & 20 \\
\hline 14.30 & 7.83 & 3116 & 3278 & 785 & 901 & 249 & 18 & 941 & 41 & 14 \\
\hline 14.35 & 0.35 & 4964 & 5783 & 1801 & 1483 & 373 & 40 & 979 & 42 & 19 \\
\hline 14.40 & I. 82 & 7261 & 7025 & 2521 & 1933 & 392 & 55 & 853 & 42 & 23 \\
\hline 14.45 & 0.38 & 6307 & 6028 & 2451 & 1787 & 343 & 48 & 764 & 37 & 19 \\
\hline 14.50 & 8.85 & 3906 & 5167 & 1480 & 1191 & 303 & 41 & 763 & 28 & 16 \\
\hline 14.55 & 8.29 & 4303 & 4812 & 1547 & 1187 & 279 & 32 & 822 & 31 & 15 \\
\hline 14.60 & 8.16 & 4643 & 4176 & 1592 & 1160 & 274 & 32 & 815 & 39 & 15 \\
\hline 14.65 & 8.47 & 4385 & 4677 & 1031 & 1155 & 285 & 33 & 949 & 45 & 14 \\
\hline 14.70 & 7.92 & 3601 & 4209 & 618 & 976 & 285 & 25 & 953 & 44 & 13 \\
\hline 14.75 & 6.88 & 2885 & 3360 & 648 & 821 & 219 & 21 & 886 & 46 & 11 \\
\hline 14.85 & 7.87 & 4006 & 3916 & 1378 & 1053 & 241 & 25 & 881 & 42 & 13 \\
\hline 14.90 & 9.53 & 4488 & 5927 & 1469 & 1223 & 303 & 37 & 915 & 41 & 15 \\
\hline 15.00 & 7.66 & 3781 & 4234 & 1080 & 1094 & 267 & 30 & 756 & 39 & 14 \\
\hline 15.05 & 8.53 & 5047 & 4569 & 1659 & 1289 & 266 & 33 & 799 & 37 & 15 \\
\hline 15.10 & 7.95 & 3360 & 4240 & 830 . & 1022 & 270 & 31 & 680 & 36 & 14 \\
\hline 15.15 & 7.84 & 3247 & 4044 & $1108^{\circ}$ & 984 & 268 & 24 & 743 & 37 & 13 \\
\hline 15.25 & 8.08 & 3404 & 4382 & 628 & 999 & 284 & 31 & 920 & 42 & 14 \\
\hline 15.30 & 8.52 & 3830 & 4613 & 1322 & 1172 & 307 & 33 & 829 & 38 & 16 \\
\hline
\end{tabular}

Table 4. Correlation matrix for $\%$ IR and elemental analyses.

\begin{tabular}{|c|c|c|c|c|c|c|c|c|c|}
\hline IR & Al & $\mathrm{Fe}$ & $\mathrm{Mg}$ & K & $\mathrm{Ti}$ & $\mathrm{Mn}$ & $\mathrm{Ba}$ & $\mathrm{Sr}$ & \\
\hline $\mathrm{Al}$ & $\underline{0.682}$ & & & & & & & & \\
\hline $\mathrm{Fe}$ & 0.908 & 0.643 & & & & & & & \\
\hline $\mathrm{Mg}$ & $\underline{0.740}$ & $\underline{0.877}$ & $\underline{0.752}$ & & & & & & \\
\hline K & $\underline{0.878}$ & $\overline{0.878}$ & 0.894 & 0.925 & & & & & \\
\hline $\mathrm{Ti}$ & 0.864 & 0.605 & 0.843 & 0.606 & 0.793 & & & & \\
\hline Mn & $\underline{0.833}$ & $\underline{0.662}$ & $\underline{0.917}$ & $\underline{0.751}$ & $\underline{0.874}$ & 0.807 & & & \\
\hline $\mathrm{Ba}$ & $\overline{0.516}$ & $\overline{0.304}$ & $\overline{0.302}$ & $\overline{0.136}$ & $\overline{0.289}$ & 0.561 & 0.233 & & \\
\hline $\mathrm{Sr}$ & 0.444 & 0.407 & 0.186 & 0.203 & 0.298 & 0.314 & 0.021 & 0.714 & \\
\hline $\mathrm{Zn}$ & $\overline{0.899}$ & 0.546 & 0.871 & 0.676 & 0.823 & 0.785 & 0.853 & $\overline{0.419}$ & 0.205 \\
\hline
\end{tabular}

Note: Underlined values are significant at the 0.01 confidence level.

likely that this frequency corresponds to the obliquity signal and should be equivalent to $41,000 \mathrm{yr}$. This would imply that the sedimentation rate for the interval studied has been underestimated and should be approximately $12.8 \mathrm{~m} / \mathrm{m}$.y., with a $5-\mathrm{cm}$ sample interval equivalent to $3.9 \mathrm{k} . \mathrm{y}$.

\section{Planktonic Foraminifers}

The relative abundance of the planktonic foraminifer Globigerinoides sacculifer (Fig. 2A) closely follows variations in $\delta^{18} \mathrm{O}$, although the maximum and minimum values sometimes precede those of the $\delta^{18} \mathrm{O}$ curve. $G$. sacculifer is a tropical species with its center of abundance in the Atlantic and Pacific oceans in the 
equatorial zone. In the present-day Indian Ocean, its maximum occurrence is predominantly south of the location of Site 709 (Bé, 1977).

Globigerinoides ruber (Fig. 2B), on which the $\delta^{18} \mathrm{O}$ values were determined, shows a similar although slightly less congruent relationship to the $\delta^{18} \mathrm{O}$ curve. Both maxima and minima of $G$. ruber tend to precede $\delta^{18} \mathrm{O}$ minima and maxima, and also the corresponding extreme values of $G$. sacculifer in some cases. $G$. ruber is also a tropical species, but it tends to reach its maximum abundances on either side of the equatorial zone in present oceans. In the modern Indian Ocean, its maximum occurrence is, like G. sacculifer, mainly south of the location of Site 709 (Bé, 1977).

Globorotalia menardii (Fig. 2C), the third species of planktonic foraminifer that we logged, shows an essentially inverse abundance relative to $G$. sacculifer and $G$. ruber. We note, however, that $G$. menardii shows a subsidiary increase at approximately the center of its trough of abundance, and that of the $\delta^{18} \mathrm{O}$ minimum, at $14.25 \mathrm{mbsf}$. This may simply be an example of the apparently anomalous nature of this part of the section, as indicated below. G. menardii is also a tropical species, but it is found most abundantly in the divergences at the margins of the Equatorial Counter Current (ECC) in the present oceans (McIntyre et al., 1989). In the Indian Ocean at the present day, it occurs in greatest abundance in a generally east-trending belt north of Site 709 (Bé, 1977).

We take the higher percentages of $G$. menardii to indicate stronger divergence in the equatorial zone, and we infer (cf. McIntyre et al., 1989) that these periods are the result of the stronger development of zonal winds relative to meridional (monsoonal) winds. This pattern would essentially parallel the late Pleistocene situation, where the weakest monsoonal conditions correlate with glacial periods (Prell and Van Campo, 1986).

We think it noteworthy that the variation in planktonic foraminifer percentages recorded in our short, but high-resolution, early Pleistocene record is at least as large as the differences in percentages between the early and late Pliocene samples from low-latitude sites recorded by Wright and Thunell (1988). This variability emphasizes the need to look for and examine highfrequency variation when comparing assemblages of different ages at any time in the late Cenozoic.

\section{Benthic Foraminifers}

Like G. menardii, the percentage of benthic foraminifer relative to total foraminifers (Fig. 3A) shows maxima at 13.55, 14.00, and $14.50 \mathrm{mbsf}$, corresponding essentially with the maxima in the $\delta^{18} \mathrm{O}$ curve. This variation could be interpreted as a result of the increased dissolution of planktonic foraminifers at these times, but the lack of evidence for increased fragmentation of planktonic foraminifers, and the parallel increases in total numbers of benthic foraminifer specimens (Fig. 3B) and of benthic foraminifer species (Fig. 3C) imply that it is more likely to have been determined by availability of food from enhanced surfacewater productivity. Such a scenario is consistent with our interpretation of enhanced surface-water divergence provided by the abundance of $G$. menardii (Fig. 2C) at the times of the $\delta^{18} \mathrm{O}$ maxima.

\section{Cd/Ca Ratios in Benthic Foraminifers}

Most $\mathrm{Cd} / \mathrm{Ca}$ ratios reported to date for benthic foraminifers are for relatively recent sediments (i.e., <0.5 m.y.; Boyle, 1988; Keigwin and Boyle, 1989). There is also one set of published data from the Miocene (Delaney and Boyle, 1987). Most of the $\mathrm{Cd} / \mathrm{Ca}$ ratios from our early Pleistocene samples analyzed so far range from 0.08 to $0.18 \mu \mathrm{mol} \mathrm{Cd} / \mathrm{mol} \mathrm{Ca}$. These values are similar to those reported for Holocene and Miocene sediments, attesting, as noted by Delaney and Boyle (1987), to the "remarkable stability of oceanic nutrient chemistry over long time intervals and despite major changes in global climate."

Assuming that the relationship between deep-water phosphorus and $\mathrm{Cd} / \mathrm{Ca}$ ratios reported by Boyle (1988) held true for the early Pleistocene, we suggest deep-water phosphorus concentrations of $1.5 \mu \mathrm{mol} / \mathrm{l}$. This is similar to present-day values in this area of $2-2.5 \mu \mathrm{mol} / 1$ (P. Statham, pers. comm., 1989). Such concentrations would be consistent with an early Pleistocene ocean circulation similar to that of the present-day ocean, although more data and a full $\mathrm{Cd}$ inventory would be required to verify this.

Our data set is currently too small to allow detailed interpretation of any systematic $\mathrm{Cd} / \mathrm{Ca}$ variation over time, particularly since the changes observed are small compared with the analytical uncertainties. If anything, our results overall should be more representative of the values to be expected in high $\delta^{18} \mathrm{O}$ (higher global ice volume) stages, because it is at these times that the benthic foraminifers are most abundant in our samples, and for which we have therefore been able to complete most analyses. It is nevertheless not obvious that the $\mathrm{Cd} / \mathrm{Ca}$ ratios are systematically either higher or lower at these times.

\section{Barite}

A detailed interpretation of $w \mathrm{t} \%$ barite fluctuations is difficult. For example, the maximum $(0.21 \mathrm{wt} \%)$ and minimum $(0.11$ $\mathrm{wt} \%$ ) values in our data set both occur during the most negative section of the $\delta^{18} \mathrm{O}$ curve, between 14.15 and $14.25 \mathrm{mbsf}$ (Fig. 4B). Moreover, the maximum value at $14.25 \mathrm{mbsf}$, which we would take to indicate highest surface productivity, coincides with the lowest ratio of benthic vs. planktonic foraminifers (Fig. $3 \mathrm{~A})$, which we have previously argued is generally correlated with the $G$. menardii evidence for periods of stronger divergence in the equatorial zone (see above). However, the \% IR is also very high at $14.25 \mathrm{mbsf}$, there is a subsidiary increase in $G$. $m e$ nardii itself at this level, and overall the 14.25-14.40 mbsf section of the core contains a number of exceptional or anomalous values (particularly for barite and \%IR; see below) that belie the relationships existing in the remainder of the sequence. At the present time, we have no totally satisfactory explanations for these. We note, however, that our values for wt $\%$ barite are lower throughout than what would be expected (Schmitz, 1987) beneath a relatively productive equatorial zone, and they may not be fully preserving an unbiased productivity record in these early Pleistocene sediments.

\section{Insoluble Residues}

Insoluble residues (\%IR) in our samples vary between $6 \%$ and $12 \%$ (Fig. $4 \mathrm{C}$ ). The relationship of the insoluble residue values to the $\delta^{18} \mathrm{O}$ curve is not immediately clear. Some of the lower IR values clearly equate with more negative $\delta^{18} \mathrm{O}$, but some of the highest values, particularly in the interval from 14.25 to $14.40 \mathrm{mbsf}$, also equate with the most negative $\delta^{18} \mathrm{O}$ values. Similarly, although there is an overall correspondence between the insoluble residues percentage and the abundance of $G$. menardii (a possible index of the strength of divergence in the equatorial zone), the relationship seems to be essentially inverted during the rapid changes of the interval from 14.25 to $14.40 \mathrm{msbf}$ (see above). A complex interrelationship between $\%$ IR and a divergence index might well be expected, because, on the one hand, increased biological productivity could lead to the dilution of the clay component by $\mathrm{CaCO}_{3}$ whereas, on the other hand, increased divergence could be associated with periods of greater zonal wind speeds, leading to an enhanced supply of clay to the equatorial Indian Ocean. 


\section{CONCLUSIONS}

Cyclicity, possibly corresponding to the Milankovitch obliquity $(41,000 \mathrm{yr})$ signal, is recorded in the planktonic $\delta^{18} \mathrm{O}$ record of early Pleistocene equatorial Indian Ocean sediments from Hole $709 \mathrm{C}$, and is also recorded by the planktonic and benthic foraminifer assemblages and, to a lesser degree, by the barite and IR contents of the sediments. Cadmium/calcium ratios in the benthic foraminifers show no clear cyclicity, although the data set is too limited to confirm this.

Periods of more positive $\delta^{18} \mathrm{O}$ ( = higher global ice volume/ cooler equatorial surface waters) are characterized by higher percentages of the tropical "divergence" planktonic species Globorotalia menardii; higher percentages, numbers, and diversity of benthic foraminifers; and generally higher percentages of barite and insoluble residues in the sediment. These periods we interpret as times of relative strengthening of the Equatorial Current System, with increased divergence, under the influence of stronger zonal winds (cf. McIntyre et al., 1989).

Conversely, periods of more negative $\delta^{18} \mathrm{O}(=$ lower global ice volume/warmer equatorial surface waters) are characterized by higher percentages of the "nondivergence" tropical species Globigerinoides sacculifer and Globigerinoides ruber; lower percentages, numbers,. and diversity of benthic foraminifers; and generally lower percentages of barite and insoluble residues in the sediment. These periods we interpret as times of relative weakening of the Equatorial Current System, with decreased divergence, during times of stronger meridional (monsoonal) winds.

There is some evidence from the planktonic foraminifer record that the equatorial changes may lead the isotopic record by $<4,000 \mathrm{yr}$, and there is also an indication, particularly from the Globorotalia menardii record, that there may be some response at a higher, possibly $\approx 20,000$-yr (precessional), frequency. However, longer data sets will be necessary to confirm whether or not these leads/lags and higher frequencies are present in the equatorial record at Site 709 .

\section{ACKNOWLEDGMENTS}

We thank the ODP shipboard party for collecting the material; N. Walsh and A. Warren for assistance with the ICP analyses, and S. J. Bennett for assistance with the XRD analyses. The ICP determinations were performed at the NERC facility at Royal Holloway and Bedford New College, Egham. We thank P. Statham for unpublished data on present-day, deep-water phosphate concentrations in the vicinity of Site 709, E. Boyle for help and encouragement, and the anonymous reviewers of this paper for their constructive criticisms. This study was supported by the U.K. Natural Environment Research Council ODP Special Topic Grant No. GST/02/320.

\section{REFERENCES}

Bé, A.W.H., 1977. An ecological, zoogeographic and taxonomic review of recent planktonic foraminifera. In Ramsay, A.T.S. (Ed.), Oceanic Micropalaeontology: London (Academic Press), 1-100.
Bé, A.W.H., and Hutson, W. H., 1977. Ecology of planktonic foraminifera and biogeographic patterns of life and fossil assemblages in the Indian Ocean. Micropaleontology, 23:369-414.

Bishop, J. K., 1988. The barite-opal-organic carbon association in oceanic particulate matter. Nature, 332:341-343.

Boyle, E. A., 1983. Chemical accumulation variations under the Peru Current during the past 130,000 years. J. Geophysical Res., 88:76677680 .

1988. Cadmium: chemical tracer of deepwater paleoceanography. Palaeoceanography, 3:471-490.

Church, T. M., 1979. Marine barite. Rev. Mineral., Mar. Minerals, 6: 175-209.

Deer, W. A, Howie, R. A., and Zussman, J., 1966. An Introduction to the Rock-Forming Minerals: London (Longmans).

Dehairs, F., Chesselet, R., and Jedwab, J., 1980. Discrete suspended particles of barite and the barium cycle in the open ocean. Earth Planet. Sci. Lett., 49:528-550.

Dehairs, F., Lambert, C. E., Chesselet, R., and Risler, N., 1987. The biological production of marine and suspended barite and the barium cycle in the Western Mediterranean Sea. Biogeochemistry, 4:119139.

Delaney, M. L., and Boyle, E. A., 1987. Cd/Ca in late Miocene benthic foraminifera and changes in the global organic carbon budget. $\mathrm{Na}$ ture, 330:156-159.

Jickells, T. D., Funnell, B. M., and Young, K. A., in press. Cadmium/ calcium ratios in benthic foraminifers recovered during ODP Leg 112. Proc. ODP, Sci. Results, 112:000-000.

Keigwin, L. D., and Boyle, E. A., 1989. Late Quaternary paleochemistry of high latitude surface waters. Palaeogeogr., Palaeoclimatol., Palaeoecol., 73:85-106.

McIntyre, A., Ruddiman, W. F., Karlin, K., and Mix, A. C., 1989. Surface water response of the equatorial Atlantic Ocean to orbital forcing. Paleoceanography, 4:19-55.

Prell, W. C., and Van Campo, E., 1986. Coherent response of Arabian Sea upwelling and pollen transport to late Quaternary monsoonal winds. Nature, 323:526-528.

Ruddiman, W. F., Raymo, M. E., Martinson, D. G., Clement, B. M., and Backman, J., 1989. Pleistocene evolution: Northern Hemisphere ice sheets and North Atlantic Ocean. Paleoceanography, 4:353-412.

Schmitz, B., 1987. Barium, equatorial high productivity, and the northward wandering of the Indian continent. Paleoceanography, 2:6377.

Shackleton, N. J., Imbrie, J., and Pisias, N. G., 1988. The evolution of oceanic oxygen-isotope variability in the North Atlantic over the past three million years. Phil. Trans. R. Soc. London, Ser. B, 318: 679-688.

Turekian, K. K., and Wedepohl, K. H., 1961. Distribution of the elements in some major units of the earth's crust. Geol. Soc. Am. Bull., 72:175-192.

Walsh, N., and Howie, R. A., 1986. Recent developments in analytical methods: uses of inductively coupled plasma source spectrometry in applied geology and geochemistry. Applied Geochem., 1:161-171.

Wright, J. D., and Thunell, R. C., 1988. Neogene planktonic foraminiferal biogeography and palaeoceanography of the Indian Ocean. Micropaleontology, 34:193-216.

Date of initial receipt: 28 June 1989

Date of acceptance: 3 January 1990

Ms 115B-176 